\title{
PERSEPSI LURAH TENTANG KETERLIBATAN AYAH DALAM PENGASUHAN DAN PENDIDIKAN ANAK USIA DINI
}

\author{
${ }^{1}$ Beatriks Novianti Kiling-Bunga, ${ }^{2}$ Yohana Krista Eka Tafuli, ${ }^{3}$ Friandry Windisany \\ Thoomaszen \& ${ }^{4}$ Indra Yohanes Kiling \\ e-mail: iykiling@gmail.com \\ 1,2Prodi Pendidikan Guru Pendidikan Anak Usia Dini Universitas Nusa Cendana \\ ${ }^{3}$ Jurusan Konseling Pastoral Sekolah Tinggi Agama Kristen Negeri Kupang \\ ${ }^{4}$ Institute of Resource Governance and Social Change
}

\begin{abstract}
Abstrak: Keterlibatan ayah dalam Pendidikan Anak Usia Dini (PAUD) merupakan bentuk partisipasi aktif dalam membantu perkembangan anak. Ayah seringkali tidak terlibat aktif di daerah dengan sistem patrilineal. Tujuan penelitian, yang dilakukan di Kupang mulai Oktober 2015 sampai dengan Maret 2016 ini adalah mengidentifikasi dan meninjau keterlibatan ayah dalam PAUD. Desain yang digunakan adalah metode kualitatif dengan teknik pengumpulan data yaitu wawancara dengan empat orang lurah sebagai partisipan. Analisis tematik dilakukan dalam proses analisis data. Hasil penelitian memperlihatkan bahwa sebagian ayah di kota Kupang sudah terlibat dalam PAUD, meski masih ada yang belum menyadari peran pentingnya dalam PAUD. Keterlibatan yang ditunjukkan masih terbatas pada pemenuhan kebutuhan ekonomi sedangkan waktu yang diluangkan untuk bersama anak masih terbatas karena tersita untuk mencari nafkah. Disarankan meningkatkan keterlibatan ayah dengan memberikan pemahaman kepada para ayah yaitu lewat kerja sama pihak pemerintah dengan para akademisi.
\end{abstract}

Kata-kata kunci: pendidikan anak usia dini, keterlibatan ayah, pengasuhan

\section{PERCEPTIONS OF URBAN COMMUNITY LEADERS IN KUPANG CITY ON FATHER'S INVOLVEMENT IN PARENTING AND EARLY CHILDHOOD EDUCATION AND DEVELOPMENT}

\begin{abstract}
Father's involvement in parenting and early childhood education and development (ECED) is a form of active participation in supporting child's development. Father does not often actively participated in parenting particularly in the community having patrilinial system. The study, conducted from October 2015 to March 2016 in Kupang, aimes at identifying father's involvement in parenting and ECE. Research design used was qualitative with interview as data collection method. Four heads of urban community participated in this reseatch. Thematic analysis was conducted.The result of the study indicates that fathers in Kupang city have involved themselves in parenting and ECED, but the involvement are limited to economic needs fulfillment while attention and emotional needs are less fulfilled. The study suggests to improve father's involvement through socializations, seminars or discussions.
\end{abstract}

Keywords: early childhood education, father's involvement, parenting

\section{PENDAHULUAN}

Pendidikan Anak Usia Dini (PAUD) merupakan suatu proses anak mendapatkan berbagai dasar pengetahuan yang nantinya bermanfaat bagi kehidupan di masa yang akan datang. Masa usia dini merupakan masa kritis dalam perkembangan manusia. Hal ini sejalan dengan hasil kajian neurologi yang menunjukkan bahwa saat lahir otak bayi membawa potensi sekitar 100 miliar yang pada proses berikutnya, sel dalam otak itu berkembang pesat dan menyambungkan bertriliun sambungan antarneuron. Supaya mencapai perkembangan optimal, sambungan ini harus diperkuat melalui berbagai rangsangan/stimulasi terhadap berbagai aspek pertumbuhan dan perkembangan (UNICEF 2013; Wahyudin dkk., 2011).

Rangsangan/stimulasi ini salah satunya 
adalah melalui perilaku pengasuhan yang dilakukan orang tua. Orang tua di sini, bukan hanya ibu saja, melainkan ayah juga. Idealnya, ayah dan ibu mengambil peranan yang saling melengkapi dalam kehidupan rumah tangga dan perkawinannya, termasuk di dalamnya berperan sebagai model yang lengkap bagi anak-anak dalam menjalani kehidupannya (Edin \& Nelson, 2013; Andayani \& Koentjoro, 2004). Dijelaskan lebih lanjut, ayah merupakan suatu peran yang dijalankan dalam kaitannya dengan tugas untuk mengarahkan anak menjadi mandiri di masa dewasanya, baik secara fisik maupun biologis.

Peran ayah dalam mengarahkan anak untuk bertumbuh dan berkembang menuju masa kedewasaan perlu ditunjukkan lewat keterlibatan ayah bersama anak. Keterlibatan yang dimaksudkan adalah suatu bentuk partisipasi secara aktif, berulang kali dan intensif dari seorang ayah yang erat kaitannya dengan pengasuhan anak. Sejalan dengan penjelasan Marsiglio dan Roy (2013) mengemukakan bahwa konsep keterlibatan ayah tidak hanya sekedar melakukan interaksi positif dengan anak, tetapi ayah juga harus memperhatikan perkembangan anak, mampu membuat kedekatan secara emosional dan rasa nyaman pada anak serta dapat memahami dan menerima anak-anak. Pengasuhan dengan ciri-ciri tersebut melibatkan kemampuan untuk memahami kondisi dan kebutuhan anak, kemampuan untuk memilih respon yang paling tepat baik secara emosional, afektif maupun instrumental.

Selain tugas pokok sebagai penyedia kebutuhan anak, ayah mempunyai perilaku pengasuhan yang khas antara lain interaksi gerak ayah-anak berorientasi pada gerak dan bermain; membantu anak bereksplorasi dan menyukai tantangan; mampu mengajarkan sikap arif, kebijaksanaan, pengambilan keputusan; ayah merupakan pendisiplin yang tegas, anak dapat belajar sikap maskulin sekaligus sebagai model pria dewasa; dan ayah merupakan peletak dasar kemampuan intelektual anak. Ayah juga memberikan afeksi, merawat anak, dan mendukung anak untuk mencapai keberhasilan (Wahyuningrum, 2014).

Penelitian tentang keterlibatan ayah yang dilakukan di luar Indonesia dalam topik pengasuhan memperlihatkan bukti betapa pentingnya ayah terlibat langsung dalam pengasuhan anak. Tinjauan sistematis mengkaji 24 penelitian secara longitudinal mengenai peran keterlibatan ayah pada perkembangan anak (Sarkadi, dkk., 2008) menunjukkan, 22 penelitian membuktikan pengaruh yang positif keterlibatan ayah. Keterlibatan ayah secara teratur dan aktif memberikan dampak yang positif, meskipun tidak diketahui bentuk khusus keterlibatan yang akan memberikan dampak lebih baik. Tinjauan sistematis ini pula memberikan kesimpulan, keterlibatan ayah memberikan dampak positif dengan berkurangnya masalah perilaku pada anak laki-laki dan masalah psikologis pada anak perempuan. Selain itu, juga akan memberikan dampak meningkatkan perkembangan kognitif, mengurangi kenakalan dan perilaku yang merugikan pada keluarga dengan status sosial ekonomi yang rendah. Hal serupa juga diperlihatkan oleh hasil penelitian lain yang menyebutkan bahwa pola asuh negatif dari ayah akan berpengaruh pada kemampuan kognitif dari anak (Shannon dkk, 2002; Tamis-LeMonda dkk., 2004).

Dari beberapa penjelasan yang dikemukakan sebelumnya, sosok ayah sangat diperlukan anak dalam tumbuh dan berkembang terutama ketika anak masih usia dini ketika belum mendapatkan stimulus dari sekolah (Harry, Bunga \& Kiling, 2015). Dengan demikian, agar para ayah semakin sadar akan peran penting yang dimiliki dalam pertumbuhan dan perkembangan anak, para ayah perlu mendapatkan pengetahuan yang mendalam tentang indikator atau kriteria yang dibutuhkan sebagai syarat dari pengasuhan yang melibatkan peran ayah di dalamnya. Di sini dibutuhkan dukungan dari berbagai segi, baik dari segi pejabat pemerintahan maupun akademisi dalam rangka menciptakan kesadaran bahwa tanggung jawab ayah bukan saja terbatas pada pemenuhan kebutuhan anak dalam hal finansial/keuangan namun juga dalam aspek emosional dan psikologis anak.

Untuk mendukung tercapainya tujuan tersebut, maka penulis merangkai penelitian ini dengan memakai sumber data primer yaitu persepsi para lurah dari kota Kupang. Pemerintahan di tingkat desa dan kelurahan merupakan unsur pemerintahan yang berhubungan langsung dengan masyarakat. Dalam penelitian ini, persepsi para lurah digunakan karena akan membantu menentukan tindakan apa yang bisa dilakukan untuk meningkatkan keterlibatan ayah dalam lingkup kelurahan. Selain itu juga, persepsi lurah digunakan untuk menghadirkan suatu kajian yang mewakili pandangan, harapan, kriteria serta indikator suatu bentuk keterlibatan ayah 
dalam pengasuhan yang dilihat dari persepsi lurah. Dengan pertimbangan para lurah yang mayoritas laki-laki dapat mewakili sosok ayah sebagai patron di setiap kelurahan masing-masing serta melihat intensitas keterlibatan ayah di kota Kupang ini lewat dua kacamata sekaligus yakni sebagai ayah dan juga sebagai pemimpin. Persepsi ini diharapkan dapat mewakili suatu situasi dalam masyarakat yang ada di beberapa kelurahan di kota Kupang.

\section{METODE PENELITIAN}

Dalam penelitian ini, menggunakan metode kualitatif deskriptif. Metode ini dianggap tepat menggambarkan persepsi seseorang terhadap suatu fenomena. Data yang diambil adalah data kualitatif menggunakan teknik wawancara terhadap empat partisipan. Wawancara dilakukan di beberapa kantor kelurahan dengan menggunakan alat perekam. Teknik analisis data yang digunakan adalah analisis tematik secara deduktif dari panduan wawancara dan juga induktif dari data hasil wawancara.

Penelitian dilakukan di kota Kupang, Provinsi Nusa Tenggara Timur dengan proses pengambilan data berlangsung dari 1 sampai dengan 16 November 2015. Proses keseluruhan penelitian berlangsung dari Oktober 2015 sampai dengan Maret 2016. Empat orang partisipan dipilih dengan mempertimbangkan lokasi dari kelurahan yang dekat dengan tempat tinggal penulis. Setelah ditentukan 10 kelurahan dengan jarak terdekat, dipilih empat kelurahan secara acak. Keempat partisipan menikah dan wawancara dilakukan di kantor lurah dengan waktu yang berbeda. Partisipan pertama berinisial EY, Kamis, 12 November 2015. Partisipan kedua berinisial YH, Senin, 16 November 2015. Partisipan ketiga berinisial BS, Senin, 16 November 2015. Partisipan yang keempat berinisial YS, Senin, 16 November 2015. Lama setiap wawancara berkisar dari 42 menit sampai dengan 1 jam 4 menit.

\section{HASIL DAN PEMBAHASAN}

Untuk memperkuat kredibilitas data secara kualitatif, peneliti (1) mengadopsi metode penelitian yang telah teruji seperti penggunaan metode wawancara setelah analisis tematik; (2) menemui partisipan terlebih dulu untuk mengembangkan rasa keakraban dengan partisipan sebelum wawancara dimulai; (3) melakukan triangulasi lokasi dengan cara memilih partisipan yang adalah lurah dari kelurahan di tengah kota serta di pinggir kota; (4) menjamin kerahasiaan data serta mendorong partisipan untuk berkata apa adanya; (5) melakukan analisis kasus negatif dengan cara mengecek lagi kategori awal dengan data set untuk mengkonfirmasi apakah kategori sesuai dengan semua poin-poin dalam fenomena; (6) bertemu dengan keempat partisipan beberapa kali dalam proses analisis untuk mendiskusikan pengalaman dan persepsi subjektif masing-masing penulis, dan (7) melakukan komentar reflektif untuk mengevaluasi proses penelitian selagi berjalan.

Refleksi penulis menemukan beberapa hal terkait penelitian yakni (1) metode wawancara saja dirasa kurang cukup, metode observasi partisipan bisa melengkapi penelitian; dan (2) melakukan wawancara di luar kantor dan di luar jam kerja akan bisa mengurangi formalitas sehingga memungkinkan penggalian data yang lebih banyak. Setelah melakukan pemberian kode, pengkategorian serta formulasi tema, ditemukan beberapa empat tema yang dijabarkan secara deskriptif di bawah ini.

\section{Cakupan dan Aktor Penyelenggaranya}

PAUD menurut persepsi partisipan pertama yakni EY, menjelaskan bahwa istilah PAUD dulu kurang dikenal, yang dikenal itu TK (Taman KanakKanak) dan PAUD itu suatu pendidikan sebelum jenjang pendidikan dasar, yang bisa disebut dengan istilah kelompok bermain. PAUD dianggap sangat menentukan pembentukan karakter anak, perkembangan dan mental anak-anak sejak dini. YH menjelaskan, PAUD itu pembentukan karakter dan di dalam kegiatan bermain itu ada unsur edukatifnya. Misalnya, ketika anak diberi kebebasan bermain peran dalam drama singkat namun dikontrol oleh guru, di situ ada aspek karakter yang turut berkembang.

Selanjutnya YS mengutarakan, PAUD merupakan bagian dari program pemerintah dalam pendidikan. Karakter dan kepribadian anak dibentuk di PAUD yang dulunya lebih dikenal dengan TK. Berbeda dengan ketiga partisipan, BS 
mendefinisikan PAUD itu mencakup banyak hal, baik itu pengasuhan yang dilakukan ayah dan ibu sejak bayi dilahirkan dan dijelaskan lebih lanjut pula, ketika orang tua menyuapi anak makanan, itu sudah PAUD karena anak dikenalkan berbagai macam rasa makanan, atau ketika anak diajarkan tentang mencuci tangan sebelum makan dan berdoa sebelum makan, itu merupakan bentuk PAUD di dalam rumah. Baru setelah usia 4-6 tahun, PAUD itu dilanjutkan oleh guru di sekolah untuk mengajarkan tentang berbagai pengetahuan lain yang belum diajarkan orang tua.

Kehadiran PAUD dikatakan sangat penting oleh keempat partisipan karena ketika di PAUD, anak dibentuk karakternya, dibentuk kepribadian dan mentalnya. Hal itu terlihat dalam perkataan EY berikut "PAUD itu penting sekali buat anak-anak karena di dalamnya anak-anak dididik untuk menjadi anak berkarakter yang baik, untuk mempersiapkan mereka agar bisa mengikuti pendidikan di Sekolah Dasar dengan baik."

Dalam penyelenggaraannya, keempat partisipan menjelaskan bahwa semua pihak baik itu orang tua, guru, dan pemerintah harus terlibat secara aktif. Semua pihak tidak boleh saling melempar tanggung jawab namun yang dibutuhkan adalah semua komponen harus mau bekerja sama guna terselenggaranya PAUD dengan lebih baik. Terlihat, partisipan menganggap PAUD krusial dalam perkembangan anak dan implementasinya harus dikawal dengan bertanggung jawab.

\section{Pentingnya Keterlibatan Ayah, Faktor-Faktor dan Bentuk Keterlibatan Ayah}

Keempat partisipan menyatakan, keterlibatan ayah sangat penting dan ayah harus berperan aktif dalam membimbing dan membina anak. Oleh karena menurut persepsi $\mathrm{YH}$, tugas ayah selain bertanggung jawab menafkahi, ia juga harus bertanggung jawab dalam berbagai hal termasuk dalam pengasuhan. Menurut YS, ayah merupakan sosok yang dijadikan figur serta contoh oleh anak maka ayah harus memberikan contoh hidup yang baik bagi anak. Bersama dengan ibu, ayah turut merawat, menjaga dan melindungi anak-anak.

Namun, menurut persepsi keempat partisipan, terkadang ada faktor yang mempengaruhi keterlibatan ayah dalam pengasuhan yaitu ayah yang terlalu sibuk bekerja mencari nafkah sehingga jarang berada di rumah. EY dan YS juga menambahkan, faktor lain yang menyebabkan ayah kurang terlibat adalah kurangnya kesadaran yang ayah miliki seperti pada kutipan berikut: "Bapak-bapak juga jadi kurang terlibat dalam pengasuhan itu karena kurangnya kesadaran, itu disebabkan mereka sonde (tidak) tahu juga, dengan bagaimana cara mengasuh yang benar itu seperti apa." (YS)

Selain itu YH dan BS menjelaskan, beberapa ayah tidak dapat terlibat dalam pengasuhan karena orang tua yang memutuskan untuk berpisah sehingga ibu saja yang mengurus anak/ ayah saja yang menjadi orang tua tunggal.

Selanjutnya, keempat partisipan menjelaskan, bentuk keterlibatan ayah dalam pengasuhan ini merupakan perilaku nyata yang harus ditunjukkan seorang ayah lewat tindakan keseharian saat di rumah, misalnya membantu ibu untuk merawat, memandikan atau memberi makan anak ketika ibu tidak di rumah. Tindakan lainnya yakni menemani anak belajar, bermain atau melakukan aktivitas lainnya. Ayah juga secara rutin mengantar jemput anak di sekolah, membayar uang sekolah, serta mencukupi kebutuhan anak dalam berbagai hal.

Kriteria Ayah yang Terlibat Dalam Pengasuhan

Beberapa kriteria yang dimiliki seorang ayah yang terlibat dalam pengasuhan menurut keempat partisipan.

1. Memberikan dukungan spesifik dalam pendidikan dan kesehatan

Keempat partisipan menjelaskan bahwa bentuk dukungan spesifik dalam hal pendidikan yaitu anak diberikan contoh perilaku yang baik dalam keseharian, dan ditanamkan nilai moral, tata krama dan sopan santun, diberikan kesempatan untuk bersekolah, bertanggung jawab memenuhi fasilitas pendidikan yang dibutuhkan anak seperti permainan, buku, seragam, dan fasilitas penunjang lainnya. Selanjutnya bentuk dukungan spesifik dalam hal kesehatan diantaranya menerapkan pola hidup sehat, menyediakan bahan makanan yang bergizi seimbang, mengantarkan anak ke rumah sakit saat anak sakit, menyediakan lingkungan tempat tinggal yang sehat dan bersih, serta memberikan contoh hidup sehat bagi anak.

2. Membangun hubungan yang akrab.

Menurut $\mathrm{YH}$, kriteria ayah yang terlibat dalam pengasuhan itu harus memiliki hubungan yang akrab dengan anak. Hubungan yang akrab ini tercermin lewat komunikasi timbal balik yang terjadi antara ayah dan anak. Ayah tidak boleh menciptakan jarak antara dirinya dan anak. Contohnya, saat anak 
menemukan hal-hal unik ketika membolak-balik buku kemudian anak bertanya "Ayah ini apa?" atau pertanyaan serupa lainnya, ayah harus menjelaskan pada anak, ayah jangan malah menyuruh anak untuk bertanya pada ibu, karena ayah beralasan sedang sibuk. Jika ayah selalu bersikap demikian, lamalama akan tercipta jarak antara ayah dan anak. Ini contoh kecil dan kadang dianggap sepele, namun bisa berakibat fatal.

\section{Memberikan perhatian kepada anak}

Selain itu, keempat partisipan menjelaskan bahwa ayah harus memberikan perhatian kepada anak misalnya dengan mengantar jemput anak ke sekolah, memberikan uang jajan, menyediakan waktu untuk bermain bersama anak-anak, serta meluangkan waktu untuk membawa anak liburan bersama dan kegiatan lainnya.

\section{Persepsi Tentang Fenomena "Ayah Mencari Nafkah dan Ibu Mengurus Anak"}

Berkaitan dengan fenomena "Ayah mencari nafkah dan ibu mengurus anak", keempat partisipan tidak setuju dengan pandangan ini. Menurut EY, saat ini kondisi tersebut tidak relevan lagi untuk diterapkan. Di kota Kupang sendiri, menurut keempat partisipan, kondisi tersebut sudah jarang ditemukan. Karena saat ini di kota Kupang bukan hanya ayah saja yang mampu bekerja mencari nafkah, ibu juga dapat bekerja untuk mencukupi kebutuhan hidup keluarga. Keempat partisipan juga menjelaskan, tugas ayah bukan hanya sebatas pada memenuhi segala kebutuhan materi/ keuangan saja namun ayah harus bekerja bersama ibu untuk merawat, melindungi serta memberikan kasih sayang dan perhatian kepada anak.

YH juga menambahkan, di Nusa Tenggara Timur (NTT) ini sebagian besar masyarakat menganut sistem patrilineal dan anak memiliki marga/ nama belakang keluarga yang selalu mengikuti marga ayah. Di sini tanggung jawab moril yang besar tersemat pada ayah untuk turut membantu ibu merawat, membimbing, dan melindungi anakanak guna menjadi dasar membentuk insan yang kompeten, yang tinggi iman, tinggi ilmu, dan tinggi pengabdian yang mampu mengharumkan nama bangsa dan negara kita. "Katong (kita) di NTT ini banyak yang menganut patrilineal. Ini bukan berarti seorang ayah pung (punya) tugas hanya untuk cari nafkah saja, tetapi di sini juga ayah punya tanggung jawab moril untuk ikut bersama-sama dengan ibu dalam membesarkan anak-anak." (YH)
Namun keempat partisipan juga menyadari sebuah realita, bukannya ayah tidak bertanggung jawab dalam pengasuhan, ayah sangat bertanggung jawab namun tanggung jawab itu kebanyakan masih terbatas pada memenuhi kebutuhan sandang, pangan, papan, pendidikan dan kesehatan. Ini dikarenakan ayah harus bekerja untuk mengatasi tuntutan ekonomi yang semakin tinggi. Akhirnya ayah lalai untuk membangun kedekatan emosional dengan anak, memberikan perhatian dan solusi bagi kehidupan anak, serta kurang peka dengan kebutuhan anak.

Selain itu menurut EY, dalam praktik kehidupan bermasyarakat, masih ada beberapa ayah di kota Kupang yang membebankan semua tugas di tangan ibu. Bukan saja tugas mengurus anak, namun juga tugas mencari nafkah juga dibebankan kepada ibu. Realita ini terjadi karena ada para ayah yang tidak punya pekerjaan tetap dan juga suka duduk berkumpul sambil mengonsumsi miras dan merokok. Menurut EY, kondisi ini memang tidak terjadi pada semua ayah, namun tidak bisa ditutupi bahwa kondisi ini terjadi di kelurahan yang dipimpinnya dan ini berdampak pula pada pengasuhan anak dalam keluarga. Di samping itu, kondisi tersebut memberikan contoh hidup yang buruk bagi anakanak.

EY mempersepsikan PAUD merupakan salah satu pendidikan sebelum jenjang pendidikan dasar. Hal ini senada dengan UU No. 20 Tahun 2003 tentang Sistem Pendidikan Nasional yang mendefinisikan PAUD sebagai suatu jenjang pendidikan sebelum pendidikan dasar, yang diselenggarakan lewat tiga jalur pendidikan yaitu jalur pendidikan formal, nonformal, dan informal.

Selanjutnya, tiga dari empat orang partisipan yakni EY, YH, dan YS berturut-turut menuturkan, PAUD, yang dulunya lebih dikenal dengan TK, merupakan kelompok bermain serta merupakan salah satu program pemerintah di bidang pendidikan. Ketiganya menyatakan fungsi PAUD itu sendiri membentuk karakter. Berdasarkan UU No. 20 Tahun 2003, ada tiga jalur pendidikan PAUD yaitu jalur formal, nonformal, dan informal serta TK merupakan PAUD formal.

Ketiga partisipan menguraikan PAUD hanya terbatas pada jalur formal (TK) dan nonformal (KB/ kelompok bermain) dan melupakan jalur informal (keluarga dan masyarakat). Padahal, keluarga merupakan jalur pertama dan utama dalam 
pendidikan. Maka dari itu, PAUD seharusnya dimulai dari dalam keluarga. Dalam UU No.23 Tahun 2002 (2002) tentang Perlindungan Anak pasal 7 ayat 1 berbunyi: "Setiap anak berhak untuk mengetahui orang tuanya, dibesarkan dan di asuh oleh orang tuanya sendiri". Didukung pula oleh UU No.20 Tahun 2003 (2003) Pasal 7 ayat 2 yang berbunyi: "Orang tua dari anak wajib belajar, berkewajiban memberikan pendidikan dasar kepada anaknya." Ini mensyaratkan bahwa anak memiliki hak untuk dicintai, disayangi, diterima, serta diasuh dan diajarkan dasar-dasar pengetahuan untuk nantinya dikembangkan lebih lanjut sejak dari dalam keluarga.

Selain itu, para partisipan mempersepsikan, PAUD itu sebuah lembaga yang lebih dikenal dengan TK dan kelompok bermain saja. Di sini terlihat bahwa pengetahuan mendalam tentang PAUD masih kurang dalam kalangan pejabat kelurahan dan ternyata kebanyakan pejabat kelurahan di kota Kupang itu juga merupakan para ayah yang memiliki anak-anak. Sesungguhnya esensi PAUD bukan saja terbatas pada lembaga melainkan merupakan suatu upaya pembinaan yang ditujukan kepada anak sejak lahir sampai dengan usia enam tahun yang dilakukan melalui pemberian stimulus pendidikan agar membantu perkembangan, pertumbuhan baik jasmani maupun rohani sehingga anak memiliki kesiapan memasuki pendidikan yang lebih lanjut (UNICEF, 2016; Yamin \& Saman, 2010).

Berdasarkan hal tersebut maka sosialisasi tentang PAUD perlu ditingkatkan lagi dan selain diadakan untuk masyarakat, hal ini pun perlu diadakan untuk para pejabat kelurahan. Karena para pejabat kelurahan inilah yang menjadi penghubung antara masyarakat dan pemerintah di tingkat pusat. Para pejabat lurah ini harus menguasai secara benar kebijakan PAUD sebelum disampaikan kepada masyarakat sehingga secara perlahan-lahan pengetahuan yang benar itu akan membantu para keluarga. Dengan demikian, para pejabat kelurahan melaksanakan fungsi yang berkaitan dengan pelayanan dan pemberdayaan kepada masyarakat.

Keempat partisipan menyatakan, ayah sangat penting terlibat dalam pengasuhan karena anak adalah hasil cinta dari sepasang laki-laki dan perempuan. Sangat tidak dibenarkan jika tanggung jawab mengasuh anak hanya dilakukan oleh salah satu pihak saja. Pendapat ini bernilai positif karena ayah sebagai salah satu elemen orangtua memiliki peran yang signifikan dalam perkembangan dan pendidikan anak, bahkan sejak anak dalam kandungan (Marsiglio, Lohan \& Culley, 2013). Hal ini sejalan dengan pendapat Supriyadi (dalam Lutfitasari \& Abdullah, 2013) yang menjelaskan, peran ayah dalam keluarga antara lain sebagai sumber kekuasaan, sebagai kepala keluarga, tokoh identifikasi, sebagai penghubung dengan dunia luar, sebagai pelindung terhadap ancaman dari luar dan sebagai pendidik yang rasional.

Namun, keempat partisipan juga menjelaskan, masih ada ayah tertentu di kota Kupang ini yang kurang menyadari pentingnya terlibat dalam pengasuhan. Penyebabnya, karena terlalu tenggelam dalam kesibukan kerja, atau kurangnya pengetahuan dan kesadaran seperti yang dikemukakan EY dan YS atau seperti yang dikemukakan oleh $\mathrm{YH}$ dan BS, kadang kala ayah tidak dapat terlibat dalam pengasuhan karena orangtua yang memutuskan untuk berpisah sehingga ibu saja yang mengurus anak/ ayah saja yang menjadi orang tua tunggal. Temuan ini sesuai dengan pendapat Shapiro (dalam Abdullah, 2009) yang menjelaskan tentang faktor yang mempengaruhi keterlibatan ayah di antaranya (1) tingkat keyakinan ayah untuk terlibat; (2) kemauan dan keinginan ibu untuk berbagi dalam membesarkan anak; (3) hubungan orang tua merupakan faktor terpenting dalam membesarkan anak; (4) faktor ekonomi; (5) aspirasi karier dan keluarga; (6) pekerjaan istri di luar rumah; (7) tersedianya bantuan tambahan; (8) status hukum seorang ayah, dimana akses para ayah yang tidak memiliki hak asuh akan menjadi sangat terbatas; (9) nilai pribadi seorang ayah; dan (10) sejarah pribadi seorang ayah.

Dari hasil wawancara dan perbandingan hasil wawancara dengan teori, penulis menemukan bahwa para ayah di Kota Kupang kebanyakan berpikir bahwa faktor ekonomi dan aspirasi karier dan keluarga menjadi faktor yang paling dominan dihadapi oleh setiap ayah. Dari penjelasan EY dan BS, kebanyakan ayah memiliki waktu yang singkat untuk bersama anaknya karena mereka harus bekerja. Dari jawaban yang diberikan oleh keempat narasumber atas pertanyaan yang penulis kemukakan adalah kebanyakan ayah berpikir bahwa lewat bekerja sesungguhnya menjadi cara mereka mau menyayangi anak-anak lewat memenuhi kebutuhan finansial anak. Tuntutan pekerjaan inilah yang membatasi waktu interaksi ayah dan anakanak. 
Kondisi lainnya yang YH dan BS jelaskan adalah para ayah kebanyakan telah menyadari arti penting keterlibatannya, namun ada beberapa juga yang belum menyadarinya. Ada ayah yang mengalami kebingungan di saat bagaimana harus bersikap ketika dihadapkan pada situasi berdua bersama anak, apa yang harus dilakukan, bagaimana harus bersikap dan tindakan pengasuhan seperti apa yang efektif. Salah satu penyebab terjadinya kebingungan ayah dalam mendidik anak adalah dunia kerja yang menuntut lebih banyak waktu dari pekerjaan, sehingga tampak seorang ayah yang sibuk bekerja, hanya pulang untuk tidur dan jarang bertatap muka dengan anak-anaknya (Lutfitasari \& Abdullah, 2013). Ayah juga semakin tidak mudah menjalankan fungsinya dalam mendidik anak karena pengaruh isteri yang bekerja. Istri yang berkarir di luar rumah membuat mereka mandiri dan tidak perlu banyak tergantung pada suami, sehingga anak yang melihat ibunya dapat berfungsi penuh tanpa keterlibatan ayah akan memandang ayahnya sebagai ayah yang lemah dan kurang berharga. Ayah menjadi kehilangan wibawa dan penghargaan di mata anaknya. Selanjutnya, ayah yang merasa tidak dihargai akan menjadi tidak nyaman di rumah dan akan menenggelamkan dirinya dalam dunia kerja. Ini memperlihatkan bahwa ibu yang membantu ayah dalam menopang ekonomi tidak semertamerta menjadi solusi akan keterlibatan ayah dalam pengasuhan (Knop \& Brewster, 2016).

Keinginan supaya ayah berperan dalam pendidikan dan pengasuhan anak tampak tidak mudah diwujudkan karena proses untuk menjadi seorang ayah yang terlibat secara aktif bukanlah hal yang mudah. Berbeda dengan wanita yang secara sosial budaya telah disiapkan untuk menjadi ibu yang mengasuh anak. Kultur masyarakat memberi ayah peran yang lebih besar dalam mencari nafkah, sehingga lebih banyak waktu, tenaga dan pikiran digunakan untuk memenuhinya. Gambaran tentang kecilnya perhatian terhadap peran ayah dalam keluarga dapat dilihat dari hasil survei yang dilakukan oleh Majalah Ayahbunda (dalam Lutfitasari \& Abdullah, 2013). Hasilnya adalah $61 \%$ responden menyatakan bahwa ayah sebaiknya menjadi pencari nafkah utama, $62 \%$ responden menyatakan bahwa hanya terlibat dalam urusan rumah tangga apabila terpaksa, dan $33 \%$ menyatakan bahwa ayah tidak perlu meluangkan waktu tiap hari untuk anak. Berdasarkan penelitian ini dan hasil survei tersebut menunjukkan bahwa sebagian ayah telah kehilangan perannya secara signifikan dalam pendidikan anak. Oleh karena itu, akan sangat membantu jika para ayah diberikan sosialisasi terkait kriteria dan bentuk-bentuk pengasuhan ayah yang efektif. Dengan demikian, para ayah dapat memposisikan diri mereka secara bijak antara karier dan keluarga.

Selanjutnya EY, YH, BS dan YS juga menjelaskan kriteria keterlibatan ayah yang terbagi atas tiga yaitu memberikan dukungan spesifik dalam bidang pendidikan dan kesehatan, membangun hubungan yang akrab, serta memberikan perhatian kepada anak, yang dibagi lagi menjadi beberapa bagian seperti pada gambar berikut:

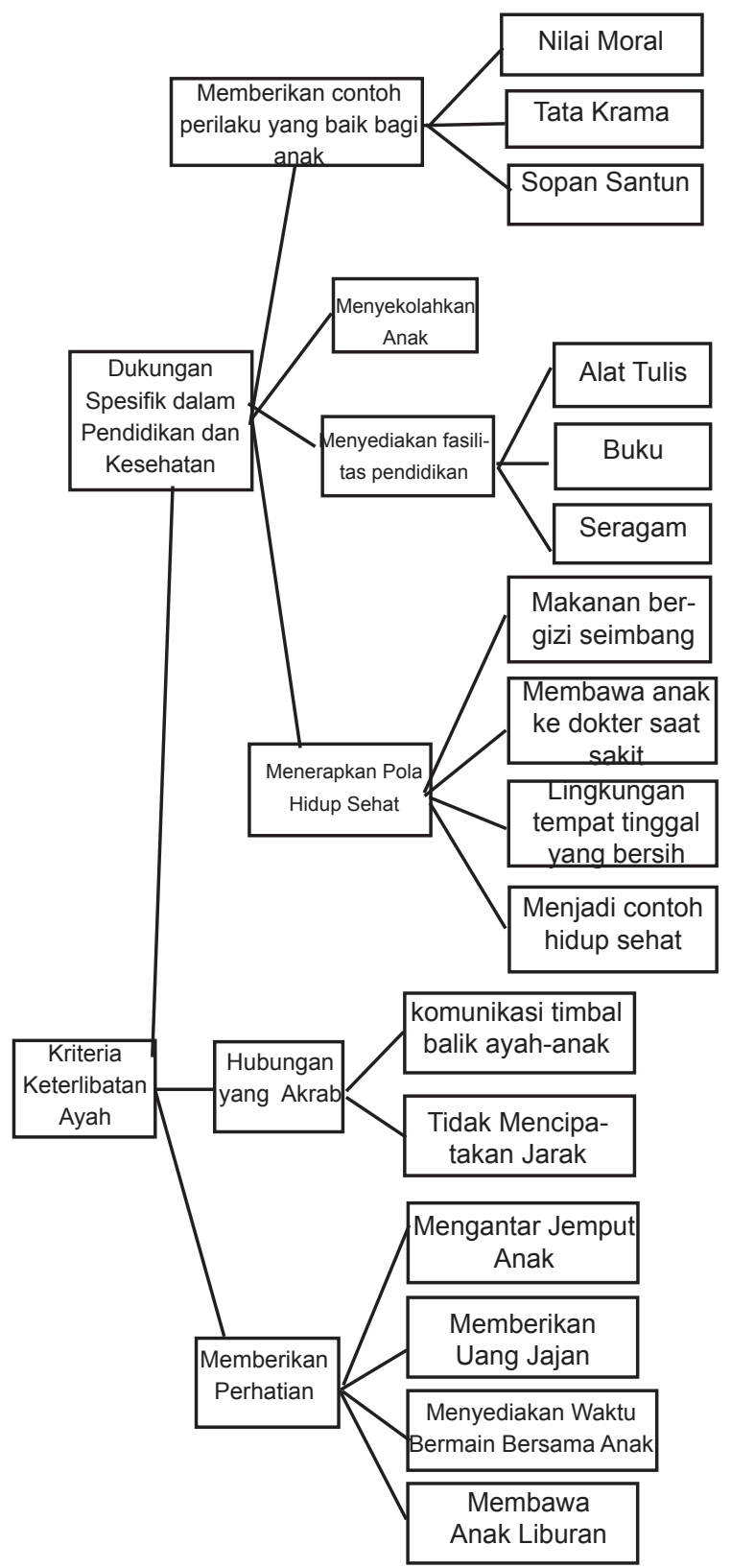

Gambar. Kriteria keterlibatan ayah dan contohcontoh kegiatannya menurut keempat partisipan 
Gambar 1 menunjukkan, kriteria menurut persepsi para lurah ini serupa dengan pernyataan Lamb dkk. (dalam Wahyuningrum, 2014) yang mengemukakan model yang elaboratif berkaitan dengan tiga dimensi keterlibatan ayah dalam pengasuhan, yaitu (a) Paternal Engagement, yaitu pengalaman ayah berinteraksi langsung dan melakukan aktivitas bersama misalnya bermainmain, meluangkan waktu bersama, dan seterusnya; (b) Paternal Accessibility, yaitu kehadiran dan kesediaan ayah untuk anak; serta (c) Paternal Responsibility, yaitu sejauh mana ayah memahami dan memenuhi kebutuhan anak, termasuk memberi nafkah dan merencanakan masa depan anak.

Hasil yang peneliti peroleh di lapangan berkaitan dengan persepsi para lurah ini sesuai juga dengan pernyataan Fox dan Bruce (dalam Wahyuningrum, 2014) yang mengemukakan konsep fathering dengan dimensi-dimensi yang diukur menggunakan aspek-aspek berikut (a) Responsivity: dimensi ini mengukur sejauh mana ayah menggunakan kehangatan, kasih sayang, dan sikap suportif kepada anaknya; (b) Harshness: dimensi ini mengukur sejauh mana ayah menggunakan sikap galak, menghukum dan pendekatan inkonsisten dalam pengasuhan kepada anaknya; (c) Behavioral enggagement: dimensi ini mengukur sejauh mana ayah menginginkan dan menyayangi anak.

Ini menunjukkan, keterlibatan ayah yang diharapkan oleh para lurah di kota Kupang yaitu suatu kondisi yang memungkinkan ayah berpartisipasi secara aktif, berulang dan secara langsung dengan anak untuk membangun komunikasi serta hubungan yang akrab dan dekat dengan anak. Maka dari itu, para ayah di kota Kupang serta di kota-kota lainnya harus membangun kedekatan hubungan dengan anak-anak dalam setiap aspek kehidupan anak. Kemudian, para ayah harus mengetahui konsep fathering ini secara lebih mendalam, dan ayah bukan saja bertanggung jawab dalam mencari nafkah namun seorang ayah harus memiliki pengalaman berinteraksi secara langsung dan beraktivitas bersama anak. Selain itu, sosok seorang ayah harus bersedia hadir bagi anaknya, serta memberikan kasih sayang, kehangatan serta sikap penerimaan bagi anaknya lewat setiap tindakan dan perbuatan seperti contoh yang disebutkan oleh keempat partisipan di atas.

Selanjutnya, membahas tentang fenomena "Ayah sebatas mencari nafkah dan ibulah yang harus mengurus anak", menurut keempat partisipan konsep ini sangat tidak relevan dengan keadaan saat ini. Menurut EY, konsep tersebut tidak relevan lagi karena pada abad 21 ini telah terjadi proses globalisasi serta kesetaraan gender. Tuntutan ekonomi yang semakin tinggi membuat para ibu harus bekerja. Selain itu, tuntutan kesetaraan gender membuat banyak wanita memiliki kesempatan yang sama seperti para pria. Namun, lebih dalam dari itu, pada dasarnya ayah dan ibu memiliki tanggung jawab yang sama untuk mengurus anak mereka. Di kota Kupang sendiri menurut EY, fenomena tersebut sudah jarang ditemukan, tetapi bukan artinya tidak ada. Ini juga didukung pula oleh $\mathrm{YH}$ yang menjelaskan bahwa konsep "Ayah sebatas mencari nafkah dan yang mengurus anak adalah tugas ibu", sangatlah tidak dibenarkan karena anak itu hasil cinta kedua orang tua.

Di NTT sendiri kebanyakan anak baik perempuan dan laki-laki dalam garis keturunan suku-suku di NTT mengikuti budaya patrilineal. Ini membuat kebanyakan anak memakai marga (nama keluarga) dari ayah. Jadi sangat tidak benar jika ayah melepas tanggung jawab pada anak dari kacamata budaya. Hal ini sesuai dengan kajian Iruka (2009) dan Fagan dkk (2014) yang menyebutkan etnis berperan dalam membentuk perilaku pola asuh dan interaksi dalam keluarga. Menurut YH dan BS, di kota Kupang ini fenomena tersebut sudah jarang terjadi karena telah banyak juga para ibu di kota Kupang ini yang turut bekerja. Namun, telah berkembang fenomena lain yang menunjukkan anak menjadi jauh dari orang tua karena ayah dan ibu sama-sama bekerja. Akhirnya anak dititipkan pada pembantu, babysitter, kakek, nenek atau orang-orang dekat lainnya. Kondisi tersebut malah menurunkan kualitas generasi bangsa yang dihasilkan.

Berdasarkan penelitian ini, implementasi keterlibatan ayah di kota Kupang yang diharapkan oleh para lurah harus mencakup partisipasi aktif, langsung dan terjadi secara berulang kali guna membangun komunikasi dan hubungan yang akrab antara ayah dan anaknya. Sudah menjadi tugas para pemimpin untuk selalu memberikan pemahaman lewat sosialisasi yang dapat membantu terwujudnya keluarga sejahtera. Implikasinya, para lurah harus memulai dengan menerapkan dahulu di keluarga sendiri, kemudian secara bertahap dan konsisten melakukan sosialisasi dan pembekalan mengenai pola asuh. Ayah harus semakin sadar 
terlibat dalam pengasuhan. Banyak cara yang dapat ayah lakukan untuk membuat hal tersebut tercapai yakni memberikan perhatian, memiliki kepekaan dan juga memulainya dengan aksi nyata. Hasil penelitian ini diharapkan dapat membantu para ayah di Kota Kupang untuk membangun gerakan sadar pengasuhan anak serta menjadi referensi bagi para pemimpin untuk mau bersinergi dengan para orang tua, guru dan akademisi guna menjadi agen yang berperan membangun konsep berpikir tentang pentingnya pendidikan sejak dini untuk anak usia dini, karena dasar-dasar pengetahuan dan kepribadian perlu ditanamkan sejak dini.

Peneliti menyadari, penelitian ini masih memiliki banyak kekurangan karena keterbatasan jumlah partisipan yang diwawancarai. Kesulitan bertemu dengan para partisipan di luar jam kerja karena waktu rutinitas yang saling bertabrakan antara penulis dan partisipan. Selain itu, kurangnya metode pengumpulan data yang digunakan juga menjadi aspek lain yang dihadapi dalam penelitian ini.

\section{PENUTUP}

\section{Kesimpulan}

Keterlibatan ayah yang diharapkan para lurah dalam PAUD di kota Kupang ialah partisipasi dan keterlibatan secara aktif, langsung dan berulang kali guna membangun kedekatan dan hubungan yang akrab dengan anak. Keterlibatan ayah itu mencakup banyak hal dan tidak hanya terbatas pada kegiatan mencari nafkah, namun harus terlibat dalam hal lainnya yakni membimbing, merawat, melindungi, memberikan perhatian dan kasih sayang, tidak menciptakan jurang pemisah antara ayah dan anak, membangun komunikasi dua arah dan timbal balik serta membangun kedekatan perasaan dan peka dengan apa yang anak butuhkan, harapkan dan inginkan.

Implikasi dari penelitian ini adalah para ayah harus menjadi semakin sadar untuk terlibat secara aktif dalam PAUD. Selain itu, ibu juga harus membantu memberikan motivasi untuk ayah agar keterlibatan ayah menjadi lebih meningkat.

\section{Saran}

Peningkatan kesadaran dapat dilakukan melalui beragam program pelatihan pengasuhan anak yang mulai sering dilakukan baik oleh dinas pendidikan maupun institusi terkait lainnya. Pelatihan harus terintegrasi dengan melibatkan semua pihak terkait dan sebisa mungkin menghindari ego sektoral penyelenggara pelatihan. Guru, pemerintah dan masyarakat serta pihak terkait lainnya harus mendukung terselenggaranya pendidikan bagi anak usia dini yang cerdas dalam ilmu dan mulia dalam akhlak. Para lurah juga bisa mempertimbangkan untuk memberikan sosialisasi melalui kata-kata sambutan yang disampaikan dalam setiap kegiatan di kelurahan. Selain itu, juga sosialisasi bisa mempertimbangkan media yang sering diakses masyarakat baik kalangan menengah ke atas maupun menengah ke bawah seperti media sosial dan/atau radio.

\section{DAFTAR PUSTAKA}

Abdullah, S. M. (2009). Keterlibatan ayah (paternal involvement) dalam pengasuhan anak (Sebuah tinjauan teoritis). Paper. Diakses dari http://fpsi.mercubuana-yogya.ac.id/wpcontent/uploads/2012/06/Keterlibatan-Ayahdalam-Pengasuhan-Anak.pdf

Andayani, B., \& Koentjoro. (2004). Psikologi keluarga: Peran ayah menuju coparenting. Cetakan Pertama. Surabaya: Citra Media.

Febryaristian (2012). Perbedaan desa dan kelurahan. Diakses dari http://febryaristian.blogspot. co.id/2012/12/perbedaan-desa-dengankelurahan_29.html

Harry, S., Bunga, B. N., \& Kiling, I. Y. (2015).
Perkembangan sosial pada anak tunarungu yang belum bersekolah. Jurnal Transformasi Edukasi, 4(1), 1-7.

Iruka, I. U. (2009). Ethnic variation in the association between family structures and practices on child outcomes at 36 months: Results from early head start. Early Education and Development, 20, 148-173.

Lutfitasari, D. S., \& Abdullah S.M. (2013). Keterlibatan ayah dalam menumbuhkan kemandirian anak pengidap diabetes melitus. Jurnal Sosio Humaniora, 4(5).

Raco, J. R. (2010). Metode penelitian kualitatif. Jakarta : Grasindo. 
Sarkadi, A., Kristiansson, R., Oberklaid, F., \& Bremberg, S., (2008). Father's involvement and children's development outcomes: A systematic review of longitudinal studies. Acta Paediatrica, 97(2), 153-158. Doi: 10.1111/j.1651-2227/2007.00572.x

Shannon, C., Tamis-LeMonda, C., London, K., \& Cabrera, N. (2002). Beyond rough and tumble: Low-income fathers' interactions and children's cognitive outcomes at 24 and 36 months. Parenting: Science and Practice, 2, 7-104.

Simasari, G. (2015). Studi deskriptif mengenai keterlibatan ayah dalam pemenuhan tugas perkembangan anak pada keluarga di tahap family with preschool children. Diakses dari http://pustaka.unpad.ac.id/wp-content/ uploads/2015/02/Ghea.pdf
Tamis-LeMonda, C., Shannon, J., Cabrera, N., \& Lamb, M. (2004). Fathers' and mothers' play with their 2- and 3-year-olds: Contributions to language and cognitive development. Child Development, 75, 1806-1820.

Undang-undang Republik Indonesia nomor 20 tahun 2003. Presiden Republik Indonesia.

Undang-undang Republik Indonesia nomor 23 tahun 2002. Presiden Republik Indonesia.

Wahyudin, H. U. \& Agustin, M. (2011). Penilaian perkembangan anak usia dini. Bandung: Refika Aditama.

Wahyuningrum, E. (2014). Peran ayah (fathering) pada pengasuhan anak usia dini. Psikowacana, 10 (1\&2), 1-19.

Yamin, H. M. \& Sanan, J. S. (2010). Panduan PAUD. Jakarta: Gaung Persada Press Group. 